Vol. V No. 2, Maret 2021, hlm. $104-110$

DOI: https://doi.org/10.36294/jmp.vxix.xxx

Available online www.jurnal.una.ac.id/indeks/jmp

\title{
PERBEDAAN KEMAMPUAN PEMECAHAN MASALAH YANG DIAJAR DENGAN APLIKASI GOOGLE MEET DAN WHATSAPP
}

\author{
Ulfah Syuhada Nasution ${ }^{\mathbf{1}}$, \\ ${ }^{1,}$ Sistem Komputer, STMIK Royal Kisaran \\ email: ulfasyuhad4@gmail.com
}

\begin{abstract}
The purpose of this study was to determine whether there were differences in student problem-solving abilities between online learning with the Google Meet application and online learning with the WhatsApp application during the Covid 19 pandemic. This type of research is a quasi-experimental research. This research was conducted on STMIK Royal Kisaran students in the SK 1A and SK 1B classes for the 2019/2020 academic year. The test technique is used to collect data about students' mathematical problem solving abilities. The test is carried out by providing in the form of essay questions in accordance with the indicators and mathematical problem solving grids that have been determined. From the results of research using the Anova test, the value of Sig. $<0.05$ was obtained, namely $0.000<0.05$. This indicates that students' mathematical problem solving abilities between online learning and Google Meet and WhatsApp are significantly different.
\end{abstract}

Keywords: Problem Solving, Google Meet, WhatsApp.

\begin{abstract}
Abstrak
Tujuan penelitian ini adalah untuk mengetahui apakah terdapat perbedaan kemampuan pemecahan masalah mahasiswa antara belajar daring dengan aplikasi Google meet dan belajar daring dengan aplikasi WhatsApp di masa pandemi covid 19. Jenis penelitian ini adalah penelitian eksperimen semu (quasi experiment). Penelitian ini dilaksanakan pada mahasiswa STMIK Royal Kisaran kelas SK 1A dan SK 1B Tahun Ajaran 2019/2020. Teknik tes digunakan untuk mengumpulkan data tentang kemampuan pemecahan masalah matematis siswa. Tes dilakukan dengan memberikan berupa soal-soal uraian (essay) sesuai dengan indikator dan kisi-kisi pemecahan masalah matematis yang telah tetapkan. Dari hasil penelitian menggunakan uji Anova, diperoleh nilai Sig . $<0,05$ yaitu $0,000<0,05$. Hal ini menyatakan kemampuan pemecahan masalah matematis mahasiswa antara pembelajaran daring dengan google meet dan whatsApp berbeda secara signifikan.
\end{abstract}

Kata kunci:Pemecahan masalah, google meet, WhatsApp.

\section{PENDAHULUAN}

Pendidikan

mempunyai peranan yang sangat penting bagi kehidupan manusia. Karena dengan adanya pendidikan, maka manusia akan mempunyai pandangan dan arah hidup yang lebih jelas dan terarah. Oleh karena itu pendidikan yang baik adalah pendidikan yang tidak hanya mempersiapkan peserta didik untuk suatu profesi atau jabatan tetapi bagaimana pendidikan dapat 
Vol. V No. 2, Maret 2021, hlm. 104 - 110

DOI: https://doi.org/10.36294/jmp.vxix.xxx

Available online www.jurnal.una.ac.id/indeks/jmp

mempersiapkan peserta didik untuk dapat menyelesaikan masalah yang akan dihadapinya dalam kehidupan sehari-hari dan mampu menerapkannya dalam kondisi apapun. Salah satu pendidikan yang harus dimiliki setiap para peserta didik adalah kemampuan matematis para peserta didik.

National Council of Teachers of Mathematic dalam (Daut, 2016), menetapkan standar-standar kemampuan matematis seperti pemecahan masalah, penalaran dan pembuktian, komunikasi, koneksi, dan representasi, seharusnya dapat dimiliki oleh peserta didik. Semua kemampuan tersebut yang diharapkan dapat dimiliki oleh peserta didik mulai dari tingkat sekolah dasar sampai tingkat sekolah menengah bahkan sampai ke perguruan tinggi.

Branca (Kartika, 2017) ia mengemukakan bahwa kemampuan pemecahan masalah adalah jantungnya matematika. Namun, kemampuan peserta didik dalam matematika masih rendah, sebagian besar siswa mengalami kesulitan dalam menyelesaikan soal-soal pemecahan masalah dan menerjemahkan soal kehidupan sehari-hari ke dalam model matematika. Sebagaimana pendapat (Mukrimatin et al., 2018), matematika dianggap sebagai pelajaran yang sulit karena karakteristik matematika yang bersifat abstrak, logis, sistematis, dan penuh dengan lambang serta rumus yang membingungkan. Di tambah lagi, dengan permasalahan pandemi di Indonesia. Yaitu pandemi covid 19. Perserikatan Bangsa Bangsa atau
PBB menyatakan bahwa salah satu sektor yang terdampak adanya wabah ini adalah dunia Pendidikan (Handarini, 2020). Hal tersebut membuat beberapa negara memutuskan untuk menutup sekolah maupun perguruan tinggi.

Sebagai upaya untuk mencegah penyebaran covid 19, WHO memberikan himbauan untuk menghentikan acara-acara yang dapat menyebabkan massa berkerumun. Banyak negara memutuskan menutup sekolahsekolah dan perguruan tinggi.

Di masa pandemi seperti ini, perkuliahan juga harus tetap dijalankan, tetapi dengan cara yang berbeda. Perkuliahan harus diselenggarakan dengan skenario yang mampu mencegah berhubungan secara fisik antara mahasiswa dengan dosen maupun mahassiswa dengan mahasiswa, sehingga setiap mahasiswa harus tetap aktif dalam perkuliahan. Perkuliahan yang biasanya dilaksanakan secara tatap muka langsung dengan dosen beralih dengan belajar dari rumah atau sering dikenal dengan belajar daring. belajar daring adalah pembelajaran yang mampu mempertemukan mahasiswa dan dosen untuk melaksanakan interaksi pembelajaran dengan bantuan internet (Kuntarto, 2017). Perguruan tinggi pada masa WFH perlu melaksanakan penguatan pembelajaran secara daring (Sadikin \& Hamidah, 2020)

Pada tataran pelaksanaanya pembelajaran daring memerlukan dukungan perangkat-perangkat mobile seperti smartphone, laptop, komputer, tablet, dan iphone yang dapat dipergunakan untuk mengakses 
Vol. V No. 2, Maret 2021, hlm. 104 - 110

DOI: https://doi.org/10.36294/jmp.vxix.xxx

Available online www.jurnal.una.ac.id/indeks/jmp

informasi kapan saja dan dimana saja (De Kock \& Futcher, 2016).

Maka dari itu, Permasalahan yang timbul pada sistem belajar dari rumah adalah dalam memilih metode yang tepat dipakai dalam proses belajar mengajar ditengah pandemi ini. Kesulitan yang ada dalam matematika menuntut kreativitas tenaga pendidik untuk mengembangkan pembelajarannya, baik dalam hal metode dan aplikasi yang digunakan.

Beberapa alternatif aplikasi yang ditawarkan harus disesuaikan dengan kondisi dosen dan peserta didik. Aplikasi yang digunakan harus mampu diakses,dan pahami oleh setiap dosen dan peserta didik agar tujuan tercapai (Anim, A. (2020). Beberapa aplikasi yang digunakan adalah Google Meet dan WhatsApp. Pengunaan google meet merupakan salah satu fitur dari google yang bisa dimanfaatkan untuk belajar daring saat social distancing untuk mencegah penyebaran virus COVID19 (Mapilindo, M., \& Anim, A. (2020), Google meet kini menjadi salah satu layanan Google yang mengalami pertumbuhan tercepat. Angka penggunanan hariannya meningkat 25 kali lipat dalam periode 2020 hingga januari 2021. Google meet menjadi versi yang lebih kuat dibanding Hangouts pendahulunya karena Google Meet mampu ditampilkan pada aplikasi web, aplikasi Android dan iOS. Google Meet memiliki Interface atau antarmuka yang unik dan fungsional dengan ukuran ringan serta cepat, mengedepankan pengelolaan yang efisien, mudah guna (user friendly) yang dapat diikuti semua pesertanya.
Selain aplikasi googel meet, Aplikasi WhatsApp saat ini juga dijadikan wadah diskusi untuk memecahkan berbagai masalah, pertanyaan dan sesuatu yang penting yang harus disampaikan terhadap orang-orang yang tergabung di dalamnya. Diskusi melalui WhatsApp ini sangat membantu penggunanya untuk berkomunikasi dalam pembelajaran jarak jauh (Yensy, 2020). Kajian terdahulu mengenai penggunaan Whatsapp Group sebagai media pembelajaran mengungkap bahwa aplikasi Whatsapp memiliki dampak positif pada kesuksesan pembelajaran dan penggunaannya, teknologi Whatsapp memiliki peran baik digunakan dalam pembelajaran (Laelasari \& Dewi, 2020).

Dengan demikian, pendidik dapat memastikan peserta didik mengikuti pembelajaran dalam waktu bersamaan, meskipun di tempat yang berbeda. Pendidik pun dapat memberi tugas terukur sesuai dengan tujuan materi yang disampaikan kepada peserta $\operatorname{didik(Herliandry~et~al.,~2020).~}$

\section{METODE}

Jenis penelitian ini adalah penelitian eksperimen semu (quasi experiment). Penelitian ini dilaksanakan pada mahasiswa STMIK Royal Kisaran kelas SK 1A dan SK 1B Tahun Ajaran 2019/2020. Teknik tes digunakan untuk mengumpulkan data tentang kemampuan pemecahan masalah matematis siswa. Tes dilakukan dengan memberikan berupa soal-soal uraian (essay) sesuai dengan 
Vol. V No. 2, Maret 2021, hlm. 104 - 110

DOI: https://doi.org/10.36294/jmp.vxix.xxx

Available online www.jurnal.una.ac.id/indeks/jmp

indikator dan kisi-kisi pemecahan masalah matematis yang telah tetapkan. Tes yang diberikan berupa soal pretest dan soal postest. Pretest diberikan sebelum pembelajaran dan postest diberikan setelah pembelajaran. Kelas eksperimen 1 (kelas SK 1A) diberi pembelajaran menggunakan aplikasi google meet. Kelas eksperimen 2 (kelas SK 1B) diberi pembelajaran dengan menggunakan Aplikasi WhatsApp. Analisis Statistik untuk uji hipotesis dalam penelitian ini menggunakan analisis varians satu arah.

Tabel 1. Ringkasan ANAVA Satu

\begin{tabular}{cccc}
\multicolumn{4}{c}{ Arah } \\
\hline $\begin{array}{c}\text { Sumber } \\
\text { Variasi }\end{array}$ & $\begin{array}{c}\text { Jlh } \\
\text { Kuad } \\
\text { rat } \\
(\mathrm{JK})\end{array}$ & $\begin{array}{c}\text { Rata- } \\
\text { rata } \\
\text { kuadr } \\
\text { at } \\
(\mathrm{RK})\end{array}$ & $\begin{array}{c}\text { Nisbah } \\
\text { F }\end{array}$ \\
\hline $\begin{array}{c}\text { PKA } \\
\text { an }\end{array}$ & JKA & $\begin{array}{c}\text { RKA } \\
\text { Perlaku }\end{array}$ & $F$ \\
Galat & JKG & $\begin{array}{c}R K G \\
=\frac{J K A}{N-k}\end{array}$ & \\
& &
\end{tabular}

Total JK

\section{HASIL DAN PEMBAHASAN}

Tes kemampuan pemecahan masalah pada kelas eksperimen 1 menggunakan pembelajaran daring dengan aplikasi google meet. Tes kemampuan pemecahan masalah matematis berupa soal - soal essay, soal diberikan setelah pemberian perlakuan pembelajaran dengan aplikasi google meet. Setiap soal tes mewakili 4 indikator kemampuan pemecahan masalah matematis. Hasil rangkuman skor total indikator yang diperoleh dari 4 soal tes dan 30 siswa untuk kelas eksperimen 1 ditunjukkan dalam Gambar 2. dibawah ini.

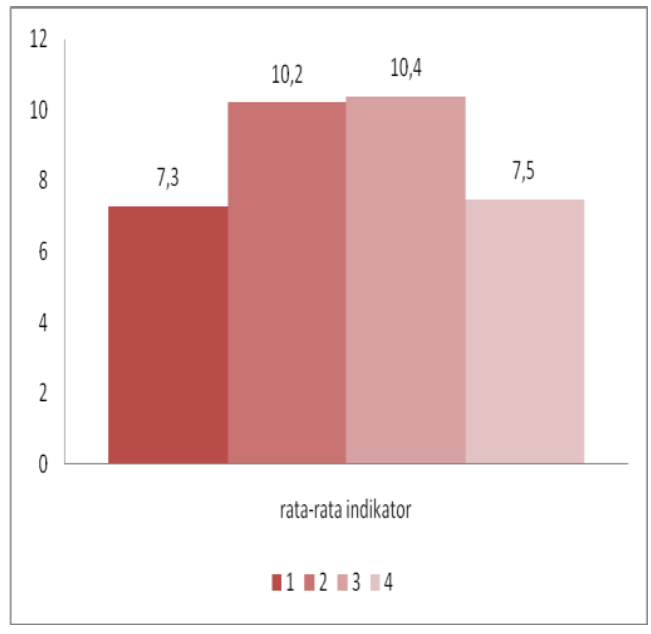

\section{Gambar 1. Diagram Kemampuan Pemecahan Masalah Matematis Kelas Eksperimen 1}

Tes kemampuan pemecahan masalah pada kelas eksperimen 2 menggunakan pembelajaran daring dengan aplikasi whatsApp. Tes kemampuan pemecahan masalah matematis berupa soal - soal essay, soal diberikan setelah pemberian perlakuan pembelajaran dengan aplikasi google meet, setiap soal tes mewakili 4 indikator kemampuan pemecahan masalah matematis. Hasil rangkuman skor total indikator yang diperoleh dari 4 soal tes dan 30 siswa untuk kelas eksperimen 2 ditunjukkan dalam Gambar 3. dibawah ini. 
Vol. V No. 2, Maret 2021, hlm. 104 - 110

DOI: https://doi.org/10.36294/jmp.vxix.xxx

Available online www.jurnal.una.ac.id/indeks/jmp

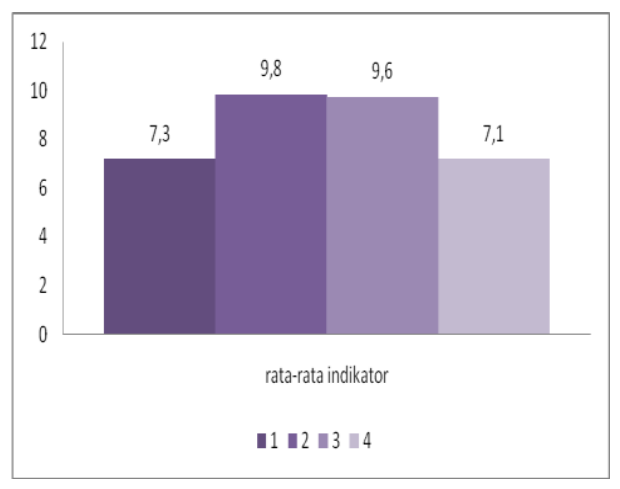

Gambar 2. Diagram Kemampuan Pemecahan Masalah Matematis Kelas Eksperimen 2

Keterangan:

1. Memahami Masalah

2. Perencanaan Strategi Penyelesaian Masalah

3. Pelaksanaan Rencana Strategi Penyelesaian Masalah

4. Pengecekan Jawaban Pemecahan Masalah

Perhitungan hipotesis dilakukan dengan uji Analisis Varian Satu Arah dapat dilakukan menggunakan software SPSS version 23.0 statistic. Hasil perhitungan uji Analisis Varian Satu Arah dapat dilakukan menggunakan software SPSS version 23.0 statistic . Dari hasil tabel 4. Anova yang diperoleh dengan menggunakan SPSS karena diperoleh nilai Sig . $<0,05$ yaitu $0,000<0,05$. Hal ini menyatakan kemampuan pemecahan masalah matematis mahasiswa antara pembelajaran daring dengan google meet dan whatsApp berbeda secara signifikan. Kemudian , dari tabel 2 dan tabel 3 dapat diambil kesimpulan bahwa kemampuan pemecahan masalah matematis mahasiswa kelas ekperimen 1 (pembelajaran dengan aplikasi google meet lebih baik dari pada kemampuan pemecahan masalah matematis mahasiswa dengan aplikasi whatsApp.

Tabel 2. Hasil Uji ANOVA Tes Kemampuan Pemecahan Masalah Matematis

\begin{tabular}{lccccc}
\hline \multicolumn{6}{c}{ ANOVA } \\
\hline postest & & & & \\
\hline & $\begin{array}{c}\text { Sum } \\
\text { of }\end{array}$ & Mea & & \\
& Squa & & \\
& & Squ & & Si \\
& res & Df & are & F & g. \\
\hline Betw & & & & & \\
een & 965, & & 482, & 18 &, 0 \\
Grou & 000 & 2 & 500 &, 5 & 00 \\
ps & & & & 6 & \\
\hline Withi & & & & & \\
n & 2260 & & 25,9 & & \\
Grou &, 625 & 87 & 84 & & \\
ps & & & & & \\
\hline Total & 3225 & & & & \\
&, 625 & 89 & & & \\
& & & & &
\end{tabular}

\section{SIMPULAN}

Dari hasil penelitian dapat disimpulkan menyatakan kemampuan pemecahan masalah matematis mahasiswa antara pembelajaran daring dengan google meet dan whatsApp berbeda secara signifikan. Kemampuan pemecahan masalah matematis mahasiswa kelas ekperimen 1 (pembelajaran dengan aplikasi google meet lebih baik dari pada kemampuan pemecahan masalah matematis mahasiswa dengan aplikasi whatsApp.

Peneliti juga menyimpulkan bahwa aplikasi google meet dan 
Vol. V No. 2, Maret 2021, hlm. 104 - 110

DOI: https://doi.org/10.36294/jmp.vxix.xxx

Available online www.jurnal.una.ac.id/indeks/jmp

whatsApp dapat digunakan untuk pembelajaran dalam masa pandemi covid 19 agar pembelajaran perkuliahan dapat berjalan secara efektif dan efisien dan semoga

\section{DAFTAR RUJUKAN}

$\begin{array}{cr}\text { Anim, A. (2020). } & \text { Persepsi } \\ \text { Mahasiswa } & \text { Pendidikan } \\ \text { Matematika rentang } \\ \text { Pembelajaran Daring } & \text { Selama } \\ \text { Masa Learn from Home (LFH) } \\ \text { Pandemic Covid-19. JURNAL } \\ \text { MATHEMATIC } \\ \text { PAEDAGOGIC, 5(1), 72-80. }\end{array}$

Daut, M. (2016). Kemampuan koneksi matematika dalam pembelajaran matematika. Journal of Mathematics Education and Science, 2(1), 58-67.

De Kock, R., \& Futcher, L. a. (2016). Mobile device usage in higher education institutions in South Africa. 2016 Information Security for South Africa Proceedings of the 2016 ISSA Conference, Celda, 27-34. https://doi.org/10.1109/ISSA.20 16.7802925

Handarini, O. I. (2020). Pembelajaran Daring Sebagai Upaya Study From Home (SFH) Selama Pandemi Covid 19. Jurnal Pendidikan Administrasi Perkantoran (JPAP), 8(3), 496503.

https://doi.org/10.1093/fampra/c my005 sebagai tenaga pengajar dapat selalu berusaha yang terbaik untuk memberikan pendidikan kepada anak didiknya.

Herliandry, L. D., Nurhasanah, Suban, M. E., \& Heru, K. (2020). Transformasi Media Pembelajaran Pada Masa Pandemi Covid-19. Jurnal Teknologi Pendidikan, 22(1), 65-70.

http://journal.unj.ac.id/unj/index .php/jtp

Kartika, H. (2017). Peningkatan Kemampuan Pemecahan Masalah dan Komunikasi Matematis Siswa Melalui Model Pembelajaran Kooperatif Tipe TPS. Jurnal Semmastika Unimed, 6(1), 1-11.

Kuntarto, E. (2017). Keefektifan Model Pembelajaran Daring Dalam Perkuliahan Bahasa Indonesia di Perguruan tinggi. Journal Indonesian Language Education and Literature, 3(1), 53-65.

http://www.syekhnurjati.ac.id/ju rnal/index.php/jeill/ PEMBELAJARAN

Laelasari, I., \& Dewi, N. P. (2020). Penerapan Pembelajaran Daring Berbasis Whatsapp Group Untuk Siswa Madrasah Ibtidaiyyah di Tengah Pandemi Covid-19. Jurnal Penelitian, 14(2), 249. 


\section{MATEMATICS PAEDAGOGIC}

Vol. V No. 2, Maret 2021, hlm. 104 - 110

DOI: https://doi.org/10.36294/jmp.vxix.xxx

Available online www.jurnal.una.ac.id/indeks/jmp

https://doi.org/10.21043/jp.v14i 2.8447

Mapilindo, M., \& Anim, A. (2020, October). PERSEPSI

MAHASISWA

FKIP

TENTANG PEMBELAJARAN DARING SELAMA PANDEMI

COVID-19.

In Seminar

Nasional Multi Disiplin Ilmu Universitas Asahan.

Mukrimatin, N. A., Murtono, M., \& Wanabuliandari, S. (2018). Pemahaman Konsep Matematika Siswa Kelas V SD Negeri Rau Kedung Jepara Pada Materi Perkalian Pecahan. ANARGYA: Jurnal Ilmiah Pendidikan Matematika, 1(1), 67-71. https://doi.org/10.24176/anargy a.v1i1.2277

Sadikin, A., \& Hamidah, A. (2020). Pembelajaran Daring di Tengah Wabah Covid-19. Biodik, 6(2), 214-224.

https://doi.org/10.22437/bio.v6i 2.9759

Yensy, N. A. (2020). Efektifitas pembelajaran statistika matematika melalui media Whatsapp Group ditinjau dari hasil belajar mahasiswa (Masa pandemik Covid 19). Jurnal Pendidikan Matematika Raflesia, 05(02), 65-74. https://ejournal.unib.ac.id/index. php/jpmr 